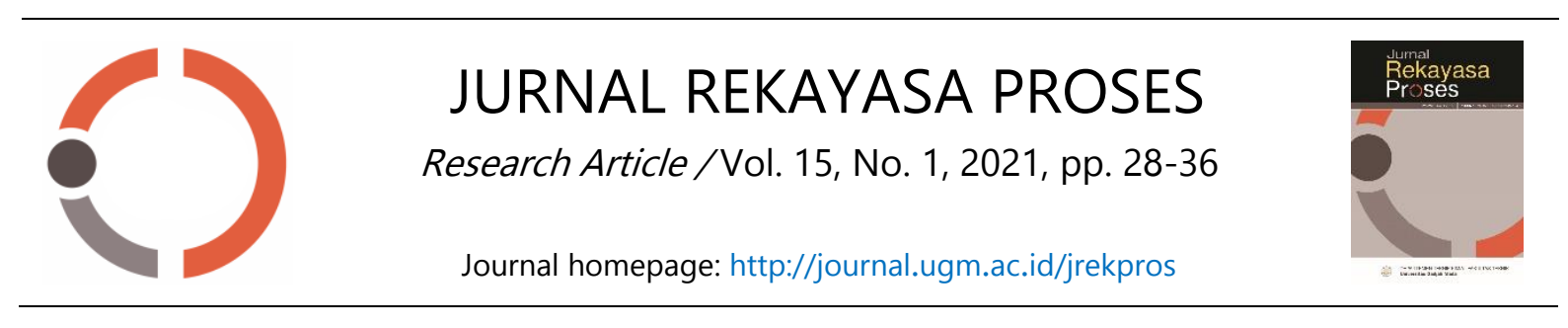

\title{
The Effects of Quartic Term Mathematical Model on The Concentration Profile of Fixed Bed Gas Adsorber
}

\author{
Ary Mauliva Hada Putri ${ }^{1,2}$ \\ ${ }^{1}$ Research Center for Chemistry-Indonesian Institute of Sciences (LIPI), Kawasan PUSPIPTEK, \\ Serpong, 15314 Tangerang Selatan \\ ${ }^{2}$ Research Center for Chemistry-National Research and Innovation Agency (BRIN), Indonesia \\ *Corresponding author: arym001@lipi.go.id
}

(Submission: 16 November 2020; Revision: 10 April 2021; Acceptance: 14 April 2021)

\section{A B S T R A C T}

The need for a reliable mathematical model depicting the process inside a column adsorber has become a requisite in designing an effective gas adsorber. Even though this task can be done by using commercial software, it is still important to get an understanding of how the entire process happens. In this paper, we discuss a new way to approximate the concentration profile inside the porous solids. It is an extension of the work of Liaw et al., who adopted a parabolic (i.e., quadratic) profile, which is a function of pellet radius while retaining the spherical symmetry. We extend their work by adding the quartic term. The inclusion of this new term still preserves the form of linear driving force approximation with some correction to Glueckauf's parameter (i.e., the effective diffusivity coefficient). The addition of the correction will affect the breakthrough curve so that it affects the saturation time. In the binary system of hydrogen/methane discussed in this study, we found that a negative correction to the diffusivity coefficient will make the saturation happen earlier compared to that of the parabolic case, and vice versa. This study may help us design an efficient gas purifier, in particular when we set out for the regeneration of the adsorbent.

Keywords: activated carbon; effective diffusivity coefficient; hydrogen; linear driving force; methane; parabolic profile

\section{ABSTRAK}

Kebutuhan model matematis yang dapat menggambarkan proses penyerapan dalam kolom adsorpsi telah menjadi kebutuhan yang tak terelakkan dewasa ini. Walaupun kini telah tersedia berbagai perangkat lunak komersial, namun tidak dapat dipungkiri bahwa memahami bagaimana proses tersebut terjadi tetap menjadi suatu hal yang berguna. Paper ini bertujuan untuk menampilkan cara baru dalam pemodelan konsentrasi adsorbat di dalam adsorben padat berpori. Kami memperluas metode yang dikembangkan Liaw et al. dengan menambahkan suku pangkat empat (kuartik). Penambahan ini akan mengoreksi koefisien 
difusivitas efektif dari persamaan linear driving force (LDF). Koreksi yang bernilai negatif, misalnya, akan mengurangi nilai koefisien difusivitas tersebut sehingga akan menghambat kemampuan adsorpsi. Hasil perhitungan kami pada sistem biner hidrogen/ metana menunjukkan bahwa suatu koreksi bernilai negatif dapat menyebabkan saturasi berlangsung lebih cepat dari kasus profil parabolik. Begitu pula sebaliknya, koreksi positif akan menambah daya adsorpsi sehingga saturasi dapat diperlambat. Studi ini kami harapkan dapat diterapkan untuk mendesain suatu kolom adsorpsi yang efisien, terutama dalam perencanaan proses regenerasi adsorben.

Kata kunci: hidrogen; karbon aktif; koefisien difusivitas efektif; linear driving force; metana; profil parabolik

\section{Introduction}

The application of gas separation has been widely found in industry, especially in the refinery process. One method largely used is adsorption. In contrast to distillation, adsorption is more suitable for low-to medium-scale industries because it does not need large volatility, hence it uses relatively less energy (Ruthven, 1984). Considering its importance, it has become unavoidable that one needs a mathematical model to simulate the process. Such mathematical model is a set of differential equations describing the dynamics of physical variables, such as concentration and temperature of the system, as the functions of time and coordinate (i.e., adsorber length). This allows us to find a set of parameters that generates optimal results (e.g., product purity).

In fixed-bed columns with porous solids, for example, there are three equations involved, i.e., (i) equation describing gas concentration in the the bulk, (ii) masstransfer equation inside the porous solids (adsorbent), and (iii) equation at the adsorbent surfaces; All three equations must be solved simultaneosuly. Although this may look straightforward, solving these three equations simultaneously can be very demanding. Such a complication, however, can be alleviated by taking some simplifying, yet justified assumptions. To name a few, they are linear driving force (LDF) approximation (Glueckauf, 1955; Glueckauf and Coates, 1947), nonlinear driving force (Kärger and Ruthven, 1992; LeVan et al., 1997; Ruthven, 1984), and parabolic profile approach (Liaw et al., 1979).

One of techniques found in literature is the approach of Liaw et al. (Liaw et al., 1979), in which the concentration profile inside the adsorbent was modeled by an isotropic with a parabolic (i.e., quadratic) function of radial coordinate. This comes from the fact that any well-behaved function can always be written in terms of power series of its variables, with higher-order terms being more and more negligible. With this assumption, the equation for gas inside the adsorbents can be eliminated, hence reducing the number of differential equations involved. The interesting thing with this approximation is that it could reproduce the Glueckauf's result of linear driving force (Glueckauf, 1955; Glueckauf and Coates, 1947), and more importantly, it could yield breakthrough curves in a good agreement with those derived by exact solution (Rosen, 1952), with considerably less computational time. 
Therefore, it is not coincident that many authors have used this approach to a more complex system, see for example (Do and Rice, 1986; Patton et al., 2004; Tsai et al., 1983; Yang et al., 1997; Yang and Doong, 1985) and references therein.

In present work, we extend the work of Liaw et al. by including the quartic term, i.e., $\mathcal{O}\left(r^{4}\right)$ term, to the concentration profile inside the porous solids of a fixed bed adsorber. Our main motivation is to see how such higherorder term affects the adsorption process. The system itself is considered to be a binary mixture of hydrogen/methane with an activated carbon as adsorbent. To the best of our knowledge, this expansion of concentration profile has not been worked out before. The inclusion of this new term retains the form of linear driving force approximation with some correction to the Glueckauf's LDF parameter (i.e., coefficient of diffusivity). We will vary the quartic parameter within its allowed value impeded by perturbativity to see how it affects the diffusivity coefficient, and in turn, breakthrough curves.

This paper is organized as follows. In Sect. 2, we will explain our approach, especially the formalism of adding the quartic coupling into the concentration profile. The results will be presented and discussed in Sect. 3. The study is concluded in Sect. 4.

\section{Methodology}

\subsection{Formalism}

The adsorber is a fixed bed column with a binary mixture of hydrogen and methane, while the adsorbent is activated carbon. The sketch of the column is depicted in Fig. 1.

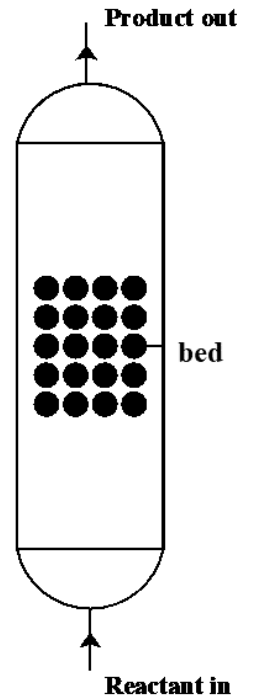

Figure 1. A vertically aligned fixed bed column

As mentioned before, in the simulation of a fixed bed column there are three differential equations involved. The first is the equation governing the concentration inside the bulk (usually called mass balance equation), i.e.,

$v \frac{\partial c}{\partial z}+\frac{\partial c}{\partial t}=-\frac{1}{\eta} \frac{\partial \bar{q}}{\partial t}$,

Here $c$ denotes the gas concentration side the bulk/column, $v$ is the flow velocity (measured at the inlet and assumed to be constant along the column), $\bar{q}$ is the mean gas concentration within the porous solids, and $\eta \equiv \epsilon /(1-\epsilon)$ with $\epsilon$ being the void parameter of the column.

Throughout this article, we will consider several assumptions regarding the column. First, it is a plug-flow system, and there is no significant axial diffusion flow. This explains the absence of the second derivative term in Eq. (1). Second, the gas concentration has no radial dependence, making Eq. (1) only depends on column dimension. Third, the temperature and pressure are uniform inside the column, so there is no need to consider the energy and momentum balance equations. The last assumption is justified because in most cases, especially when the 
concentration and the length are not very large, the effects of such variations are so small that they can be omitted in the first place.

Inside the porous solids, there exists an equation:

$$
\frac{\partial q}{\partial t}=\frac{D_{e}}{r^{2}} \frac{\partial}{\partial r}\left(r^{2} \frac{\partial q}{\partial r}\right)
$$

with $D_{e}$ and $r$ denoting the diffusion coefficient and the adsorbate radial coordinate, respectively. These two equations are related to each other through Eq. (3).

$$
D_{e}\left(\frac{\partial q}{\partial r}\right)_{r=R}=k\left(c-q_{R} / K\right) \text {, }
$$

where $q_{R}$, as the symbol suggests, is the mole fraction at the surface of the adsorbent with radius $R, k$ is the mass transfer coefficient, and $K$ is the adsorption equilibrium constant.

One can see that in Eq. (1), $q$ (or $\partial q / \partial t$ ) is expressed in average form, which is defined as:

$$
\bar{q}=\frac{3}{R^{3}} \int_{0}^{R} q r^{2} d r .
$$

It is then straightforward to find $\partial \bar{q} / \partial t$. That is,

$$
\frac{\partial \bar{q}}{\partial t}=\frac{3}{R^{3}} \int_{0}^{R}\left(\frac{\partial q}{\partial t}\right) r^{2} d r=\frac{3 D_{e}}{R}\left(\frac{\partial q}{\partial r}\right)_{r=R}
$$

where we have used Eq. (2). Equation (4) suggests that should we know the $q$ dependence on radial coordinate, $\partial \bar{q} / \partial t$ can be determined. This is the essence of Liaw et al. (Liaw et al., 1979).

We assume that $q$ be expressed as a power series expansion (Eq. (6)).

$$
q=a_{0}+a_{1} r+a_{2} r^{2}+\ldots
$$

with $a_{n+1} r \ll a_{n}$. Thanks to the finiteness of $q$, there is no term with negative power of $r$, and therefore such series can be truncated at some power of $r$. We further assume that $q$ is spherically symmetric function, meaning that all odd powers vanish or $a_{2 n+1}=0$. In the present case we will keep up to $\mathcal{O}\left(r^{4}\right)$ term, so $q$ takes the form of:

$$
q=a_{0}+a_{2} r^{2}+a_{4} r^{4}
$$

Now by using Eq. (7), we find $(\partial q / \partial r)_{r=R}=$ $2 a_{2} R\left(1+2 a_{4} R^{2} / a_{2}\right)$. Similar to (Liaw et al., 1979), it would be more useful if one can state this derivative in terms of physical quantities $q_{R}$ and $\bar{q}$, namely:

$$
\begin{aligned}
& \mathrm{q}_{\mathrm{R}}=\mathrm{a}_{0}+\mathrm{a}_{2} R^{2}+a_{4} R^{4} \\
& \bar{q}=a_{0}+\frac{3}{5} a_{2} R^{2}+\frac{3}{7} a_{4} R^{4}
\end{aligned}
$$

Taking into consideration that $\left(a_{4} / a_{2}\right) R^{2}$ is much less than 1 , so it can be treated a perturbation parameter, we then obtain Eq. (10).

$$
\left(\frac{\partial q}{\partial r}\right)_{r=R}=\frac{5}{R}(1+\beta)\left(q_{R}-\bar{q}\right)
$$

with

$$
\beta \equiv \frac{4}{7}\left(\frac{a_{4} R^{2}}{a_{2}}\right) .
$$

From Eq. (5) the linear driving force relation follows Eq (12)

$$
\frac{\partial \bar{q}}{\partial t}=\frac{15 D_{e}}{R^{2}}(1+\beta)\left(q_{R}-\bar{q}\right) .
$$

As expected, the inclusion of the quartic term in the concentration profile leads to a correction to the Glueckauf's constant parameter. (In the work of Liaw et al., since they have quadratic function, $\beta=0$, which is the reason of why they end up similarly as Glueckauf's LDF.) One may have noticed that the parameter $\beta$ of Eq. (11) is treated like a constant. That is, both $a_{4}$ and $a_{2}$ have the same time dependence. One may argue that, in general, it is not always true as each expansion coefficient $a_{i}$ may have different time dependence. We justify it by noting that it is $\bar{q}$ that enters Eq. (1). Therefore, $\bar{q}$ (or more precisely $\partial \bar{q} / \partial t$ ) consists of $r$ and $t$ functions 
that are always separable. This is the chief reason of why each coefficient $a_{i}$ has the same time dependence.

Next, we would like to see how $\beta$ enters the differential equation and subsequently affects the breakthrough curves. Apart from $\beta$, Eq. (12) pretty much looks like the one discussed in (Liaw et al., 1979). So we follow their procedure to eliminate $q$ and to simplify Eq. (1). We start by transforming variables $z$ and $t$.

$$
\begin{aligned}
& x=z /(\eta v) \\
& \theta=t-z / v
\end{aligned}
$$

The two new variables have time dimension, although they have different physical meaning; variable $\theta$ accounts for a real relative time while $x$ describes a gas traveling time with velocity $v$ along a column that has a length $z$. Hence, one can consider $x$ as a length expressed in time dimension.

In terms of $x$ and $\theta$, Eq. (1) becomes Eq. (15).

$$
\frac{\partial c}{\partial x}=-\frac{\partial \bar{q}}{\partial \theta},
$$

or by using Eq. (12) we obtain Eq (16).

$$
\frac{\partial c}{\partial x}=-\frac{15 D_{e}}{R^{2}}(1+\beta)\left(q_{R}-\bar{q}\right) .
$$

By taking derivative with respect to $\theta$ on both sides followed by using Eqs. (3) and (1), we can express $\bar{q}$ in terms of $q_{R}$ and $c$ as Eq. (17).

$$
\bar{q}=\left(1+\frac{R k}{5 D_{e}(1+\beta) K}\right) q_{R}-\frac{R k}{5 D_{e}} c .
$$

Now, we eliminate $q_{R}$ by taking the derivative with respect to $\theta$ followed by using Eq. (15). We finally get Eq. (18).

$$
\frac{\partial c}{\partial x}=-K \frac{\partial c}{\partial \theta}-\xi \frac{\partial^{2} c}{\partial x \partial \theta},
$$

with

$$
\xi \equiv R\left(\frac{K}{3 k}+\frac{R}{15 D_{e}(1+\beta)}\right) \simeq R\left(\frac{K}{3 k}+\frac{R}{15 D_{e}}(1-\beta)\right)
$$

The boundary conditions are given by Eq. (20)

$$
\begin{array}{ll}
c=0 & \text { for } \theta \leq 0 \text { and } \forall x \\
c=c_{0} & \text { for } \theta>0 \text { and } x=0,
\end{array}
$$

where $c_{0}$ is the initial gas concentration fed at the inlet.

What we want from solving the aforementioned differential equation is to observe how the adsorption for each molecule occurs. In particular, we would like to see when the breakpoint (i.e., saturation) starts to occur. By knowing it, we can avoid the buildup of the unwanted gas inside the column, so we can start the regeneration process of the adsorbent. For our purpose, the breakpoint is defined to occur when $c / c_{0}=1 \%$.

\subsection{Model parameters}

Having elaborated the required formalism, we now address the parameters used in this article. We first discuss the effective diffusivity coefficient $D_{e}$ given in Eq. (2). Such parameter is given by (Yang et al., 1997; Yang, 1987) according to Eq. (21).

$$
\frac{1}{D_{e}}=\left(\frac{1}{D_{m}}+\frac{1}{D_{k}}\right) \tau
$$

where $D_{m}$ is the molecular diffusivity, $D_{k}$ is the Knudsen diffusivity, and $\tau$ is the tortuosity, i.e., a parameter describing the diffusion characteristics of the porous media. For activated carbon, $\tau$ ranges from 5 to 65 . In this analysis $\tau$ will be fixed at 30 . The molecular diffusivity is given according to the ChapmanEnskog relation of Eq. (22).

$$
D_{m}=1.8583 \times 10^{-3} \sqrt{T^{3}\left(\frac{1}{M_{1}}+\frac{1}{M_{2}}\right)}\left(P \sigma_{i} \Omega_{i}\right)^{-1},
$$

with $\sigma_{i}$ and $\Omega_{i}$ denoting the parameter of Lennard-Jones potential and collision integral, respectively. The procedure of how to calculate these two parameters is outlined in literature, see for example Bird et al. (Bird 
et al., 2006). As for the Knudsen diffusivity, it is given by $\mathrm{Eq}(23)$.

$$
D_{k}=9.7 \times 10^{-3} r_{p} \sqrt{\frac{T}{M}}
$$

with $r_{p}$ being the pore radius, which is much smaller than the adsorbent radius $R$.

Both $k$ and $K$ (see Eq. (3)) denote, respectively, the mass transfer coefficient and the equilibrium constant. The former is derived from Eq. (24) (Yang, 1987).

$$
\frac{2 k R}{D_{m}}=2+1.1 \mathrm{Sc}^{1 / 3} \mathrm{Re}^{0.6}
$$

while the latter is obtained by linearizing the extended Langmuir relation of Eq. (25).

$$
q_{i}^{*}=\frac{q_{s i}^{*} b_{i} p_{i}}{1+\sum_{j} b_{j} p_{j}}
$$

with $p_{i}$ being the partial pressure for species $i, b_{i}$ and $q_{s i}$ follow Eq. (26).

$$
b_{i}=b_{0 i} e^{b_{1 i} / T}, \quad q_{s i}=a_{1 i}+\frac{a_{2 i}}{T} .
$$

The values of all parameters used throughout this article are given in Tables 1 and 2 .

Table 1. Parameter values of the gases used in the calculation. The molecular properties are taken from Park et al. (Park et al., 1998)

\begin{tabular}{lcccccc}
\hline Component & $\begin{array}{l}a_{1, i} \\
\times 10^{3}\end{array}$ & $\begin{array}{c}a_{2, i} \\
\end{array}$ & $\begin{array}{c}b_{0 i} \\
\times 10^{7}\end{array}$ & $b_{1, i}$ & Mass & $\rho$ \\
\cline { 2 - 7 } & $(\mathrm{mol} / \mathrm{g})$ & $(\mathrm{K})$ & $(1 / \mathrm{mmHg})$ & $(\mathrm{K})$ & $(\mathrm{g} / \mathrm{mol})$ & $\mathrm{kg} / \mathrm{m}^{3}$ \\
\hline $\mathrm{CH}_{4}$ & -1.78 & 1.98 & 26.60 & 1446.7 & 16.04 & 0.657 \\
$\mathrm{H}_{2}$ & 4.32 & 0 & 6.72 & 850.5 & 2.016 & 0.082 \\
Temperature & & & $298 \mathrm{~K}$ & & \\
Pressure & & & $20 \mathrm{~atm}$ \\
Column length & & & $100 \mathrm{~cm}$ \\
Flow velocity & & & $0.5 \mathrm{~cm} / \mathrm{s}$ \\
\hline
\end{tabular}

\section{Results and Discussion}

Based on the information given in the previous section, we now discuss the effect of the quartic term in the hydrogen/methane separation with activated carbon. We solve the differential equation of Eq. (18) for both hydrogen and methane with boundary conditions given by Eq. (20).

Table 2. Parameter values of activated carbon being used in the calculation. Taken from Yang and Doong (Yang and Doong, 1985)

\begin{tabular}{ll}
\hline Quantity & Value \\
\hline Adsorbent radius & $0.028 \mathrm{~cm}$ \\
Pore radius & $1.6 \mathrm{~nm}$ \\
Inter-particle void fraction $(\epsilon)$ & 0.35 \\
Intra-particle void fraction $(\alpha)$ & 0.61 \\
Adsorbent density & $0.85 \mathrm{~g} / \mathrm{cm}^{3}$ \\
\hline
\end{tabular}

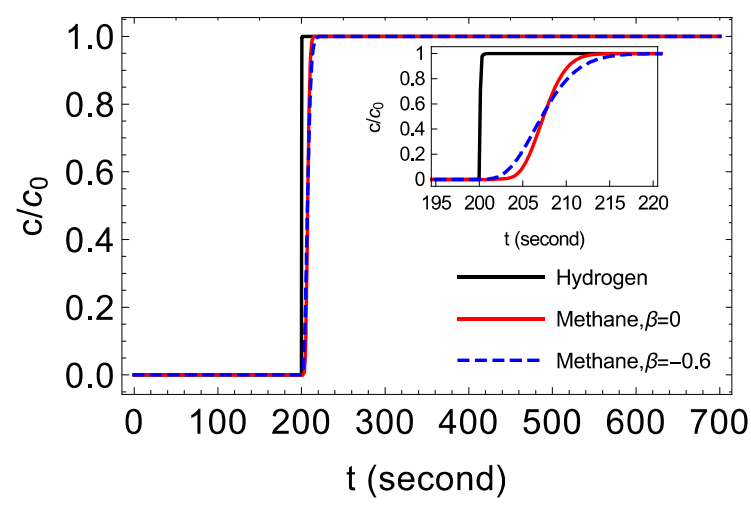

Figure 2. The breakthrough curves showing the effects of saturation time on the gas adsorption

The results is presented in the form of a breakthrough curve shown in Fig 2. In so doing, we assume that the column length be $100 \mathrm{~cm}$ and the flow velocity be $0.5 \mathrm{~cm} / \mathrm{s}$; the temperature and pressure are fixed at $298 \mathrm{~K}$ and 20 atm, respectively. By using Eq. (21) and following the procedure of Yang and Doong (Yang and Doong, 1985), we obtain the effective diffusivity coefficients of hydrogen and methane to be $4.1 \times 10^{-4}$ $\mathrm{cm}^{2} / \mathrm{s}$ and $1.9 \times 10^{-4} \mathrm{~cm}^{2} / \mathrm{s}$, respectively. Despite having relatively larger $D_{e}$, it is not always true to say that the activated carbon will adsorb hydrogen better than it does on methane. It turns out that the equilibrium constant $K$ (see Eq. (18)) proves to play the upper hand. From the Langmuir relation, the 
equilibrium constant of hydrogen is found to be $K_{H_{2}} \simeq 0.00012$, which is almost two orders of magnitude smaller than $K_{\mathrm{CH}_{4}} \simeq 0.02$. Such equilibrium constants resemble the lowpressure regime of Park et al. (Park et al., 1998). Higher $K$ indicates that the corresponding molecule is more likely to occupy the sorption sites, and vice versa. Considering these values, it is expected that hydrogen will get saturated earlier than methane, so this column can be considered as a hydrogen purifier.

Our conjecture above is supported from Fig. 2, in which the adsorption of hydrogen (solid black line) reaches saturation about three seconds before the methane starts to build up inside the adsorbent (here we refer to the solid red line, depicting a parabolic concentration profile of methane). From the same figure we can also see that the presence of a negative $\beta$ will shorten such time gap. This can be understood by recalling that the negative $\beta$ will lower the effect of $D_{e}$ (see Eq. (18)), making the buildup of methane inside the column occur a bit faster. In our example of Fig. 2, the time gap is reduced from $3 \mathrm{~s}$ into about $1.5 \mathrm{~s}$ for $\beta=-0.6$ (blue dashed line). Conversely, a positive $\beta$ will make the effect of $D_{e}$ larger, leading to buildup of methane at later time. This result gives an estimate when one should start the regeneration of the adsorbent.

However, it should be noted that the value of $\beta$ is limited by perturbativity; that is, it cannot be much grater or even very close to one. The value of $|\beta|=0.6$ in our example is barely considered perturbative, and thus it is presented here only for the sake of illustration. In reality, it seems more plausible to have much smaller $|\beta|$ whose precise value can only be determined through data fitting.

\section{Conclusions}

We have extended the work of (Liaw et al., 1979), where we add a quartic term to the concentration profile. The inclusion leads to a correction to Glueckauf's linear driving force parameter (i.e., the effective diffusivity coefficient $D_{e}$ ). Depending on its sign, the presence of such quartic coupling (denoted as $\beta$ ) could increase or decrease $D_{e}$. A negative $\beta$, for instance, will decrease the effect of the diffusion, leading to relatively faster saturation compared to that of parabolic profile (zero $\beta$ ). The opposite is true for a positive $\beta$. Despite this, a data fitting is needed to further reveal the value of $\beta$.

\section{Acknowledgements}

The author thanks J. Julio of Research Center for Physics-Indonesian Institute of Sciences (LIPI) for suggesting this topic and his guidance in doing this article.

\section{List of notations}

\section{Latin letters}

$a_{0}, a_{1}, a_{2}, \ldots$ Expansion coefficients of the adsorbate, dimensionless

$a_{1 i}, a_{2 i}, b_{0 i}$, Langmuir isotherm parameters $b_{i} \quad$ for the $i$-th molecule, $\mathrm{mol} / \mathrm{g}$

$c_{i} \quad$ The $i$-th gas concentration $D_{e} \quad$ The effective diffusivity coefficient, $\mathrm{cm}^{2} / \mathrm{s}$

$k_{i} i=1,2 \quad$ Mass transfer coefficient for the $i$-th gas, $\mathrm{cm}^{2} / \mathrm{m}^{2}$.s

$M_{i} \quad$ The $i$-th molecular mass, $\mathrm{gr} / \mathrm{mol}$

$P, P_{i} \quad$ Total gas pressure, partial gas pressure, atm

Pr Prandtl number, dimensionless 


$\begin{array}{ll}q_{i}, \bar{q}, q^{*} & \begin{array}{l}\text { The i-th gas inside the } \\ \text { adsorbent, average concen- } \\ \text { tration of the adsorbate, the } \\ \text { equilibrium concentration of } \\ \text { the adsorbate, mol/g }\end{array} \\ & \text { Radial coordinate inside the } \\ r & \text { adsorbent, } \mathrm{cm} \\ r_{p} & \text { Pore radius, } \mathrm{cm} \\ R & \text { Radius of adsorbent, } \mathrm{cm} \\ t & \text { Time, } \mathrm{s} \\ T & \text { Gas temperature, }{ }^{0} \mathrm{~K} \\ \mathrm{Sc} & \text { Schmidt number, dimension- } \\ & \text { less } \\ \mathrm{Re} & \text { Reynolds number, dimension- } \\ v & \text { less } \\ x & \text { Gas flow velocity, } \mathrm{cm} / \mathrm{s} \\ z & =z /(\eta v) \text { in time dimension, } \mathrm{s}\end{array}$

\section{Greek letters}

$\alpha$

$\begin{array}{ll}\epsilon & \text { Inter-particle void fraction, } \\ & \text { dimensionless } \\ \theta & \text { Gas density, } \mathrm{g} / \mathrm{cm}^{3} \\ & =t-z / v, \text { a new coordinate } \\ & \text { expressing relative time, } \mathrm{s}\end{array}$

\section{References}

Bird, R.B., Stewart, W.E. and Lightfoot, E.N., 2006, Transport Phenomena, 2nd ed., Wiley, New York

Do, D.D. and Rice, R.G., 1986, Validity of the parabolic profile assumption in adsorption studies, AIChE J., 32 (1), 149-154.

Glueckauf, E., 1955, Theory of chromatography. Part 10. Formulæ for diffusion into spheres and their application to chromatography, Trans. Faraday Soc., 51 (0), 1540-1551.
Glueckauf, E. and Coates, J.I., 1947, Theory of chromatography. Part IV. The influence of incomplete equilibrium on the front boundary of chromatograms and on the effectiveness of separation, J. Chem. Soc., 1315-1321.

Kärger, J. and Ruthven, D.M., 1992, Diffusion in Zeolites and Other Microporous Solids, Wiley, New York

LeVan, M. D., Carta, G. and Yon, C. M., 1997, Adsorption and ion exchange, in Perry, R. and Green, D. (Eds.), Perry's Chem. Eng. Handb., 7th ed., McGraw-Hill, New York, p. 16.

Liaw, C.H., Wang, J.S.P., Greenkorn, R.A. and Chao, K.C., 1979, Kinetics of fixed-bed adsorption: A new solution, AIChE J., 25 (2), 376-381.

Park, J.-H., Kim, J.-N., Cho, S.-H., Kim, J.-D. and Yang, R.T., 1998, Adsorber dynamics and optimal design of layered beds for multicomponent gas adsorption, Chem. Eng. Sci., 53 (23), 3951-3963.

Patton, A., Crittenden, B.D. and Perera, S.P., 2004, Use of the linear driving force approximation to guide the design of monolithic adsorbents, Chem. Eng. Res. Des., 82 (8), 999-1009.

Rosen, J.B., 1952, Kinetics of a Fixed Bed System for Solid Diffusion into Spherical Particles, J. Chem. Phys., 20 (3), 387-394.

Ruthven, D.M., 1984, Principles of Adsorption and Adsorption Processes, Wiley, New York.

Tsai, M.C., Wang, S.S. and Yang, R.T., 1983, Pore-diffusion model for cyclic separation: Temperature swing separation of hydrogen and methane at elevated pressures, AIChE J., 29 (6), 966-975.

Yang, J., Lee, C.-H. and Chang, J.-W., 1997, Separation of hydrogen mixtures by a two- 
bed pressure swing adsorption process using zeolite 5A, Ind. Eng. Chem. Res., 36 (7), 2789-2798.

Yang, R.T., 1987, Gas Separation by Adsorption Processes, Elsevier, available at:https://doi.org/10.1016/C2013-004269-7.

Yang, R.T. and Doong, S.J., 1985, Gas separation by pressure swing adsorption: $A$ pore-diffusion model for bulk separation, AIChE J., 31 (11), 1829-1842. 